University of Nebraska - Lincoln

DigitalCommons@University of Nebraska - Lincoln

Agronomy \& Horticulture -- Faculty Publications

Agronomy and Horticulture Department

2005

\title{
Soil Surface Fluxes of Greenhouse Gases in an Irrigated Maize- Based Agroecosystem
}

Brigid Amos

University of Nebraska-Lincoln, bamos2@unl.edu

Timothy J. Arkebauer

University of Nebraska-Lincoln, tarkebauer1@unl.edu

John W. Doran

University of Nebraska-Lincoln, jdoran1@unl.edu

Follow this and additional works at: https://digitalcommons.unl.edu/agronomyfacpub

Part of the Plant Sciences Commons

Amos, Brigid; Arkebauer, Timothy J.; and Doran, John W., "Soil Surface Fluxes of Greenhouse Gases in an Irrigated Maize-Based Agroecosystem" (2005). Agronomy \& Horticulture -- Faculty Publications. 321.

https://digitalcommons.unl.edu/agronomyfacpub/321

This Article is brought to you for free and open access by the Agronomy and Horticulture Department at DigitalCommons@University of Nebraska - Lincoln. It has been accepted for inclusion in Agronomy \& Horticulture -Faculty Publications by an authorized administrator of DigitalCommons@University of Nebraska - Lincoln. 


\title{
Soil Surface Fluxes of Greenhouse Gases in an Irrigated Maize-Based Agroecosystem
}

\author{
Brigid Amos,* Timothy J. Arkebauer, and John W. Doran
}

\begin{abstract}
An understanding of the effect of fertility management on soil surface fluxes of $\mathrm{CO}_{2}, \mathrm{~N}_{2} \mathrm{O}$, and $\mathrm{CH}_{4}$ is essential in evaluating $\mathrm{C}$ sequestration measures that attempt to increase the amount of crop residue returned to the soil through increased fertilizer inputs. In this study, soil surface $\mathrm{CO}_{2}$ flux was measured over a 27-mo sampling period in continuous maize (Zea mays $\mathbf{L}$.) plots managed under either an intensive fertility regime (M2) or recommended best management (M1). Flux was significantly higher in the M2 treatment on only $2 \mathrm{~d}$ during the first growing season. Annual estimates of soil surface $\mathrm{CO}_{2}$ flux, based on a modified exponential equation that incorporates leaf area index (LAI) to predict temporal changes in soil respiration, averaged $11550 \mathrm{~kg} \mathrm{C} \mathrm{ha}^{-1} \mathrm{yr}^{-1}$ for both treatments (approximately $31.64 \mathrm{~kg} \mathrm{C} \mathrm{ha}^{-1} \mathrm{~d}^{-1}$ on average). Within row soil surface $\mathrm{CO}_{2}$ flux was, on average, $64 \%$ higher than between row flux. Plant population did not significantly affect measured soil surface $\mathrm{CO}_{2}$ flux. While fertility management had no significant effect on $\mathrm{CH}_{4}$ flux, $\mathrm{N}_{2} \mathrm{O}$ flux as measured on $\mathbf{3} \mathrm{d}$ during the $\mathbf{2 0 0 0}$ growing season was significantly higher in the M2 treatment. In 2001, no significant differences in $\mathrm{N}_{2} \mathrm{O}$ flux were observed, possibly due to changes in $\mathbf{N}$ management and irrigation method. Electrical conductivity measured during the 2000 and 2001 growing seasons was significantly higher in the M2 treatment while $\mathrm{pH}$ measured during the 2001 season was significantly lower for M2.
\end{abstract}

$\mathrm{O}$ NE TACTIC in the effort to sequester $\mathrm{C}$ in agricultural soils is to increase soil organic $\mathrm{C}$ by increasing plant density and soil fertility, thus increasing the amount of biomass produced and the amount of crop residue returned to the soil (Lal et al., 1998; Varvel, 1994). Yet soil is also a large source of $\mathrm{CO}_{2}$ due to the respiratory activities of its inhabitants, with approximately $10 \%$ of the atmosphere's $\mathrm{CO}_{2}$ passing through terrestrial soils each year (Raich and Potter, 1995). To fully assess a $\mathrm{C}$ sequestration effort, an accounting of all greenhouse gas fluxes must be made, including those that occur at the soil surface. Several maize studies have examined the effect of synthetic $\mathrm{N}$ application on soil surface $\mathrm{CO}_{2}$ flux as compared with unfertilized or lightly fertilized controls. Rochette and Gregorich (1998) found that after $3 \mathrm{yr}$ of $\mathrm{NH}_{4} \mathrm{NO}_{3}$ application to a maize field at a rate of $200 \mathrm{~kg} \mathrm{~N} \mathrm{ha}^{-1}$, field-measured soil surface $\mathrm{CO}_{2}$ flux was not significantly different from that of a control receiving no amendments. Wagai et al. (1998) compared field-measured soil surface $\mathrm{CO}_{2}$ flux in maize plots receiving either 10 or $189 \mathrm{~kg} \mathrm{~N} \mathrm{ha}^{-1}$ and found

B. Amos and T.J. Arkebauer, University of Nebraska-Lincoln, Dep. of Agronomy and Horticulture, Lincoln, NE 68583-0915; J.W. Doran, USDA-ARS Soil and Water Conservation Research Unit, Lincoln, NE 68583-0934 . A contribution of the University of Nebraska Agricultural Research Division, Lincoln, NE 68583. Journal Series No. 14525. Received 17 Mar. 2004.*Corresponding author (bamos2@unlnotes. unl.edu).

Published in Soil Sci. Soc. Am. J. 69:387-395 (2005).

(c) Soil Science Society of America

677 S. Segoe Rd., Madison, WI 53711 USA that the fertilizer treatment was significant for only 1 out of 19 sampling dates. However, we know of no studies that have compared soil surface $\mathrm{CO}_{2}$ flux in maize receiving standard recommended $\mathrm{N}$ levels and those receiving intensive levels designed to achieve maximum yield potential and increase crop residue.

In addition to $\mathrm{CO}_{2}$, increasing levels of atmospheric $\mathrm{N}_{2} \mathrm{O}$ and $\mathrm{CH}_{4}$ are of particular concern due to their considerably higher global warming potentials (GWP) relative to $\mathrm{CO}_{2}$. For example, over a 20 -yr time period, $1 \mathrm{~kg}$ of $\mathrm{N}_{2} \mathrm{O}$ will have 275 times the influence on global warming as $1 \mathrm{~kg}$ of $\mathrm{CO}_{2}$ (Intergovernmental Panel on Climate Change [IPCC], 2001). Nitrous oxide is produced when plant-available $\mathrm{N}$ forms are subjected to the bacterial processes of denitrification and nitrification (Firestone and Davidson, 1989), and various studies have shown that $\mathrm{N}_{2} \mathrm{O}$ emission from agricultural soil is significantly increased by application of synthetic $\mathrm{N}$ fertilizers (Linn and Doran, 1984; Bronson and Mosier, 1993). Global $\mathrm{N}_{2} \mathrm{O}$ emissions from row-crop agriculture are assumed to be the greatest contributor to global $\mathrm{N}_{2} \mathrm{O}$ flux (Robertson, 1993), with cultivated soils comprising $27 \%$ of the total $\mathrm{N}_{2} \mathrm{O}-\mathrm{N}$ added from all known sources (Beauchamp, 1997). Soils comprise between 3 and 9\% of the total sink for atmospheric $\mathrm{CH}_{4}$ due to consumption by methanotrophs in aerobic soils (Sylvia et al., 1998). Few studies have examined the effect of fertilizer application on $\mathrm{CH}_{4}$ uptake by cultivated soils. While Bronson and Mosier (1993) found that urea fertilization of irrigated wheat and corn did not affect $\mathrm{CH}_{4}$ uptake, Powlson et al. (1997) determined that $150 \mathrm{yr}$ of N application to wheat plots maintained at a neutral $\mathrm{pH}$ reduced $\mathrm{CH}_{4}$ uptake by $50 \%$.

The objectives of this study were (i) to determine the effect of different fertility management regimes on annual patterns of soil surface $\mathrm{CO}_{2}$ flux in a continuous maize production system, (ii) to develop an empirical model for prediction of soil surface $\mathrm{CO}_{2}$ flux based on relevant controlling factors (i.e., soil temperature, soil water content, LAI), which would then be used to estimate total annual soil $\mathrm{CO}_{2}$ flux under different fertility management regimes in continuous maize by means of integrating predicted values over the course of a year, and (iii) to determine the effect of different fertility management regimes on soil surface fluxes of $\mathrm{N}_{2} \mathrm{O}$ and $\mathrm{CH}_{4}$.

\footnotetext{
Abbreviations: $\mathrm{EC}_{1: 1}$, soil electrical conductivity measured in a one to one soil distilled water suspension; GWP, global warming potential; IPCC, Intergovernmental Panel on Climate Change; M1, recommended best management fertility treatment; $\mathrm{M} 2$, intensive fertility treatment; P1, low plant population; P2, medium plant population; P3, high plant population; TP, total porosity; WFPS, water-filled pore space.
} 


\section{MATERIALS AND METHODS}

\section{Study Site}

This study was conducted on selected plots of the Ecological Intensification of Irrigated Maize-based Cropping Systems Experiment at the University of Nebraska-Lincoln East Campus in Lincoln, NE (40 $50^{\prime} \mathrm{N}$ lat., and $96^{\circ} 39^{\prime} \mathrm{W}$ long.). This experiment was established in 1999 with the following objectives which are independent from those of the present study: (i) to quantify and understand the maximum yield potential of maize and soybean (Glycine max L.) under irrigated conditions, (ii) to identify efficient crop management practices to achieve yields that approach maximum yield potential levels, and (iii) to determine the energy-use efficiency, GWP, and soil $\mathrm{C}$-sequestration potential of intensively managed maize systems. To meet the objectives of the overall experiment, various management changes were made during the course of the present study to maximize yield and resource-use efficiency. The soil is a deep Kennebec silt loam (fine-silty, mixed, superactive, mesic Cumulic Hapludoll). Before this experiment, the field had been planted to a sorghum (Sorghum bicolor Moench.)soybean rotation without $\mathrm{N}$ fertilizer for $10 \mathrm{yr}$. During the 1998 growing season, the field was in soybeans. Initial soil tests performed in March 1999 on the 0- to 0.2-m layer showed a $\mathrm{pH}$ of 5.3, $27 \mathrm{~g} \mathrm{~kg}^{-1}$ soil organic matter, $67 \mathrm{mg} \mathrm{kg}^{-1}$ Bray$\mathrm{P}$, and $350 \mathrm{mg} \mathrm{kg}^{-1}$ exchangeable $\mathrm{K}$. Nitrate-N concentration in the 0 - to $0.3-\mathrm{m}$ layer was $5.1 \mathrm{mg} \mathrm{kg}^{-1}$. The field was limed in the fall of 1999 after harvest with $3.81 \mathrm{Mg} \mathrm{ha}^{-1}$ of $\mathrm{CaCO}_{3}$ equivalents and again in the fall of 2001 with $6.52 \mathrm{Mg} \mathrm{ha}^{-1}$ of $\mathrm{CaCO}_{3}$ equivalents. Planting dates were 13 May 1999, 21 Apr. 2000, and 26 Apr. 2001. The maize hybrid planted in 1999 and 2000 was Pioneer 33A14 while Pioneer 33P67 (Pioneer HiBred International, Inc., Johnston, IA) was planted in 2001.

\section{Management Treatments}

The continuous maize systems compared in this study included three maize plant populations $(\mathrm{P} 1=69200-76600$ plants ha ${ }^{-1}, \mathrm{P} 2=86400-98800$ plants ha $^{-1}$, and P3 $=108700$ 116100 plants $\mathrm{ha}^{-1}$ ), and two nutrient management regimes: recommended best management (M1) and intensive management (M2). The M1 N treatment was based on the current University of Nebraska-Lincoln, Department of Agronomy and Horticulture $\mathrm{N}$ algorithm. The input for this algorithm included a yield goal of approximately $12500 \mathrm{~kg}_{\text {grain ha }}{ }^{-1}$, $\mathrm{NO}_{3}^{-}-\mathrm{N}$ concentration, and organic matter content, and was intended to follow best management practices for maize. Fertility management in the M2 treatment was designed to be nonlimiting and to supply $\mathrm{N}, \mathrm{P}$, and $\mathrm{K}$ to meet the requirements of a higher plant population and yield goal (approximately $16300-16900 \mathrm{~kg}$ grain $\mathrm{ha}^{-1}$ in the first year of production with an ultimate goal of $18800 \mathrm{~kg}$ grain ha ${ }^{-1}$ in subsequent years). This higher yield goal was based on the best estimate of maximum yield potential for maize under the climatic conditions in southeast Nebraska. The overall experiment is a splitsplit plot randomized complete block design with four replicates. The main plots are two crop rotations (continuous maize and maize-soybean), the subplots are the plant populations, and the sub-subplots are the two fertility treatments. Measurements of greenhouse gas fluxes were made in the individual sub-subplots. These sub-subplots covered eight rows and were 6.1 by $12.2 \mathrm{~m}$ in size. Although no permanent control plots were established for this study, when feasible, measurements were also made in the unfertilized borders at the edges of the field and between plots. These control areas covered eight rows and were 6.1 by $24.4 \mathrm{~m}$ in size, and measurements were made in the inner four rows of these areas. The plant population in these control areas was P3 (108700-116100 plants $\left.\mathrm{ha}^{-1}\right)$.
Table 1. Dates of $\mathrm{NH}_{4} \mathrm{NO}_{3}-\mathrm{N}$ application, growth stages, and rates of $\mathbf{N}$ application for the two fertility treatments in continuous maize plots.

\begin{tabular}{|c|c|c|c|c|}
\hline Year & Treatment & Date & Growth stage & $\mathbf{N}$ \\
\hline & & & & $\mathrm{kg} \mathrm{ha}^{-1}$ \\
\hline \multirow[t]{7}{*}{1999} & M1 & 13 Apr. & Preplant & 65 \\
\hline & & 7 June & V6 & 65 \\
\hline & & & Total & 130 \\
\hline & M2 & 13 Apr. & Preplant & 105 \\
\hline & & 7 June & V6 & 60 \\
\hline & & 30 June & V10 & 60 \\
\hline & & & Total & 225 \\
\hline \multirow[t]{7}{*}{2000} & M1 & 4 Apr. & Preplant & 103 \\
\hline & & 24 May & V6 & 100 \\
\hline & & & Total & 203 \\
\hline & M2 & 4 Apr. & Preplant & 103 \\
\hline & & 24 May & V6 & 130 \\
\hline & & 8 June & V10 & 130 \\
\hline & & & Total & 363 \\
\hline \multirow[t]{8}{*}{2001} & M1 & 9 Apr. & Preplant & 100 \\
\hline & & 25 May & V5 & 100 \\
\hline & & & Total & 200 \\
\hline & M2 & 9 Apr. & Preplant & 100 \\
\hline & & 25 May & V5 & 80 \\
\hline & & 15 June & V8-9 & 80 \\
\hline & & 5 July & VT & 40 \\
\hline & & & Total & 300 \\
\hline
\end{tabular}

Table 1 shows the $\mathrm{N}$ application schedule for the two fertility management regimes in continuous maize during the three growing seasons. Granular preplant fertilizer was broadcast and disked, and for the M2 treatment, included supplemental nutrients in addition to $\mathrm{NH}_{4} \mathrm{NO}_{3}$. In 1999, the M2 preplant fertilizer included $\mathrm{P}, \mathrm{K}, \mathrm{S}$, and Fe applied at the rates of 44, 84,20 , and $10 \mathrm{~kg} \mathrm{ha}^{-1}$, respectively. In 2000 , the M2 preplant fertilizer included $\mathrm{P}, \mathrm{K}, \mathrm{S}, \mathrm{Fe}$, and $\mathrm{Zn}$ applied at 45, 85, 21, 12 , and $6 \mathrm{~kg} \mathrm{ha}^{-1}$, respectively. In 2001, the preplant fertilizer applied to the M2 plots included only $45 \mathrm{~kg} \mathrm{ha}^{-1} \mathrm{P}$ and $85 \mathrm{~kg}$ $\mathrm{ha}^{-1} \mathrm{~K}$ as supplemental nutrients. Subsequent $\mathrm{N}$ was applied as $\mathrm{NH}_{4} \mathrm{NO}_{3}$ and was surface broadcast between the rows. The plots were kept well watered during the growing season through a drip tape system. During the 1999 and 2000 growing seasons, the tape ran along the base of the plants in every row. In 2001, the drip tape was buried at a depth of 30 to $38 \mathrm{~cm}$ at a $60-\mathrm{cm}$ spacing beneath the between row area to conserve water as well as avoid rodent damage.

\section{Soil Surface Carbon Dioxide Flux}

Soil surface $\mathrm{CO}_{2}$ flux was measured on $62 \mathrm{~d}$ from May 1999 through August 2001 by attaching an $819-\mathrm{cm}^{3}$ chamber with a 7.3-cm inner diameter to a Li-Cor Inc. LI-6200 Portable Photosynthesis System (Li-Cor Inc., Lincoln, NE) as described by Norman et al. (1992). Within each plot, four soil surface $\mathrm{CO}_{2}$ flux measurements were made at randomly chosen points, two at the within row position between plants (or as close to the base of the plants when brace roots formed) and two measurements at the between row position approximately equidistant from two adjacent rows. Within row and between row measurements were averaged together to determine treatment means. The sampling schedule for the various treatments is shown in Table 2. Soil $\mathrm{CO}_{2}$ flux measurements were made in the full set of plots at 1- to 2-wk intervals during the first two growing seasons (1999 and 2000). From late fall to early spring, a smaller number of measurements were made at less frequent intervals. During the third growing season (2001), soil $\mathrm{CO}_{2}$ flux measurements were made in only two of the four blocks since these measurements were made as part of a separate study in which $\mathrm{CO}_{2}$ flux is compared in the two rotations (data not shown here).

Measurements of soil temperature and moisture were made in conjunction with each flux measurement. Soil temperature 
Table 2. Summary of soil surface $\mathrm{CO}_{2}$ flux measurements made in continuous maize on selected treatments of the UNL Ecological Intensification Experiment, Lincoln, NE.

\begin{tabular}{lll}
$\begin{array}{l}\text { Plant } \\
\text { population }\end{array}$ & Fertility treatment & \multicolumn{1}{c}{ Sampling period } \\
\hline P1, P2, and P3 & M2 & 27 May 1999-9 Oct. 1999 \\
P2 & $\begin{array}{l}\text { M1 and M2 } \\
\text { P3 }\end{array}$ & $\begin{array}{l}\text { 11 June 1999-18 Aug. 2001 } \\
\text { (Control) }\end{array}$ \\
\hline
\end{tabular}

was measured at the 0.1-m depth adjacent to each chamber position using a thermistor thermometer (Cole-Parmer model 8110-20). Water content was also measured in the top $0.1 \mathrm{~m}$ of soil to determine water-filled pore space (WFPS) by means of either gravimetric sampling with a soil core $(\mathrm{d}=1.9 \mathrm{~cm})$ or with a nondestructive probe (HydroSense, Campbell Scientific Inc., Logan, UT) and calibration curve for this soil. Waterfilled pore space was calculated by dividing volumetric water content $\left(\theta_{\mathrm{v}}\right)$ by total soil porosity (TP) (Linn and Doran, 1984). Water-filled pore space is reported here as a percentage but is used as a fraction in empirical equations. Bulk densities from the soil cores were used in calculations of $\theta_{\mathrm{v}}$ and TP when gravimetric samples were taken. During use of the HydroSense, additional soil cores were taken periodically to determine average within row and between row bulk density for WFPS calculations. At various times during the growing season it was necessary to substitute WFPS readings from an adjacent M1 plot for WFPS of a particular M2 plot when the HydroSense readings were unusually high due to higher electrical conductivity of the M2 treatment (presumably due to the higher soil $\mathrm{NO}_{3}^{-}$content of these plots).

\section{Nitrous Oxide and Methane Flux}

Nitrous oxide and $\mathrm{CH}_{4}$ fluxes were measured on $3 \mathrm{~d}$ during the 2000 growing season (23 May, 12 July, and 24 August) and on $3 \mathrm{~d}$ in 2001 (17 May, 24 July, and 22 August). These samples were taken in the $\mathrm{P} 2$ plant population of continuous maize for the M1 and M2 treatments, as well as in the control areas adjacent to each continuous maize block. Two static chambers per plot were installed in the between row location. These chambers had a diameter of $15 \mathrm{~cm}$ and covered an area of $176.7 \mathrm{~cm}^{2}$, and could be closed with a vented lid. They were inserted (without lids) into the soil to a depth of $7.5 \mathrm{~cm}$ at least $24 \mathrm{~h}$ before sampling, leaving a head space of $1325 \mathrm{~cm}^{3}$. Using a syringe, $20-\mathrm{mL}$ gas samples were extracted through a septum in the lid of each chamber at 0,15 , and $30 \mathrm{~min}$ after closing. These samples were then injected into $10-\mathrm{mL}$ evacuated vials sealed with septa and aluminum collars. Nitrous oxide and $\mathrm{CH}_{4}$ were analyzed by means of an automated gas sampling system attached to a gas chromatograph (Varian 3700) as described by Arnold et al. (2001). Fluxes were calculated using an equation published by Hutchinson and Mosier (1981), which assumes that flux decreases over time due to a decrease in the concentration difference between the soil and the headspace. For data that did not fit this assumption, flux was calculated from the slope of concentration versus time curve. Soil moisture and temperature was measured at each chamber using the techniques described above.

\section{Electrical Conductivity, $\mathrm{pH}$, and $\mathrm{NO}_{3}^{-}-\mathrm{N}$}

In 2001, measurements of $\mathrm{EC}_{1: 1}, \mathrm{pH}$, and $\mathrm{NO}_{3}^{-}-\mathrm{N}$ were made in the laboratory on subsamples taken from soil cores (top $7.5 \mathrm{~cm}$ ) collected at the time of $\mathrm{N}_{2} \mathrm{O}$ and $\mathrm{CH}_{4}$ sampling. Electrical conductivity was determined for a 1:1 soil-water suspension (by mass) with a conductivity meter (Markson model 1062). A pH meter (Oaktron 510 series) was then used to determine the $\mathrm{pH}$ of the 1:1 soil-water suspensions. A separate subsample of dry soil was analyzed for $\mathrm{NO}_{3}^{-}-\mathrm{N}$ content by means of water extraction and $\mathrm{Cd}$ reduction (Gelderman and Beegle, 1998). Electrical conductivity was also measured in the field in the top $7.5 \mathrm{~cm}$ of soil with a conductivity meter (Hanna Instruments Dist WP, Woonsocket, RI) adapted for in situ measurements by John Doran and Spencer Arnold of the USDA-ARS Soil and Water Conservation Research Unit, Lincoln, NE. The instrument was mounted on a pole and wired to metal probes that were pushed directly into the soil. In 2000, the first version utilized copper probes. Electrical conductivity was measured in 2000 near each static chamber in the between row area whenever $\mathrm{N}_{2} \mathrm{O}$ and $\mathrm{CH}_{4}$ fluxes were measured. A sturdier version with steel probes was assembled in 2001. This version also allowed for a temperature correction of EC readings. In 2001, in situ EC measurements were made concurrent with the 24 July and 22 to 23 August $\mathrm{N}_{2} \mathrm{O}$ and $\mathrm{CH}_{4}$ samples. On 24 July 2001, $500 \mathrm{~mL}$ of distilled water was poured into each chamber after gas samples were extracted, and EC was measured later in the evening within the chamber. In situ EC measurements were made on 23 Aug. 2001, approximately $24 \mathrm{~h}$ after addition of the $500 \mathrm{~mL}$ of distilled water. Distilled water was used in 2001 to reduce the variability of field EC measurements attributable to variability in soil water content. Analysis of variance was performed for all sampling days.

\section{RESULTS AND DISCUSSION}

\section{Soil Surface Carbon Dioxide Flux-Population and Fertility Effects}

Average soil surface $\mathrm{CO}_{2}$ flux, soil temperature at the 0.1-m depth, and WFPS in the top $0.1 \mathrm{~m}$ for the three plant populations of continuous maize under the M2 fertility treatment in 1999 are shown in Fig. 1. Average $\mathrm{CO}_{2}$ flux was relatively low early in the growing season from the V2 stage, day of year (DOY) 147, through V10

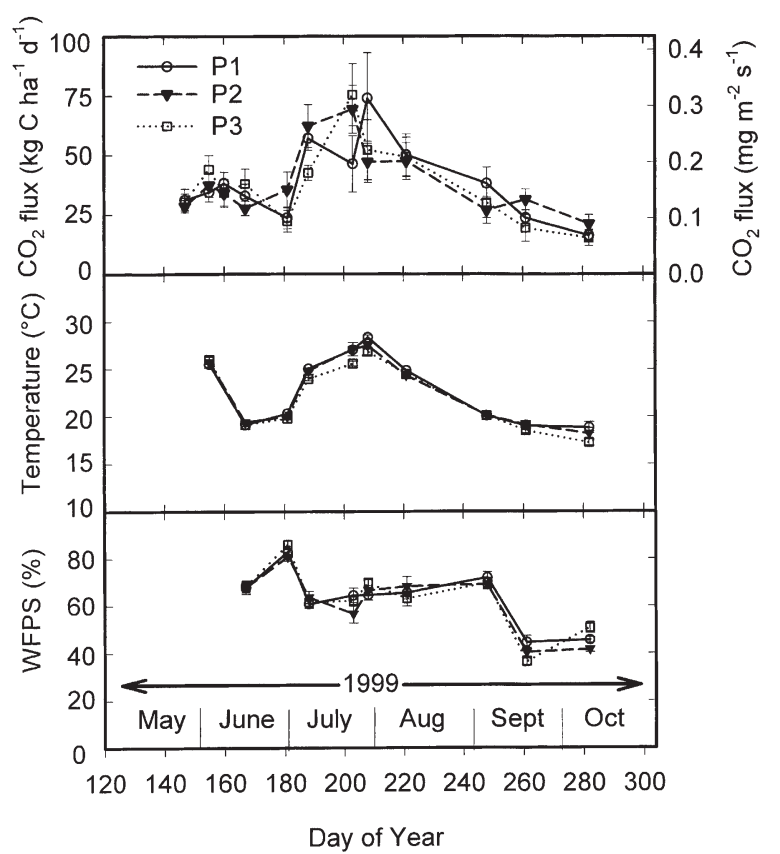

Fig. 1. Soil surface $\mathrm{CO}_{2}$ flux measured in continuous maize at three plant populations $\left(\mathrm{P} 1=69200-76600\right.$ plants $^{-1}, \mathrm{P2}=86400$ 98800 plants $\mathrm{ha}^{-1}$, and $\mathrm{P3}=108700-116100$ plants ha ${ }^{-1}$ ) under the M2 (intensive) fertility treatment during the 1999 growing season. Also shown are soil temperature at the $0.1-\mathrm{m}$ depth and waterfilled pore space in the top $0.1 \mathrm{~m}$ of soil. 


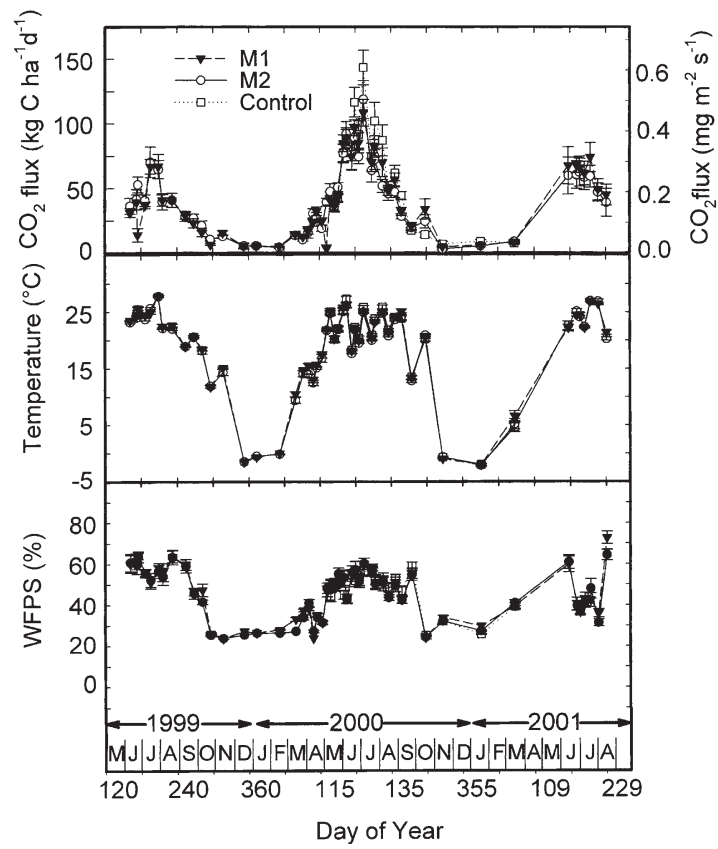

Fig. 2. Soil surface $\mathrm{CO}_{2}$ flux measured in continuous maize for the P2 (86 400-98 800 plants $\mathrm{ha}^{-1}$ ) plant population at the two fertility treatments $(\mathrm{M} 1=$ recommended best management; $\mathrm{M} 2=$ intensive) and in the unfertilized control at the P3 (108 700-116 100 plants ha ${ }^{-1}$ ) plant population during the 27-mo study. Also shown is soil temperature at the $0.1-\mathrm{m}$ depth and water-filled pore space in the top $0.1 \mathrm{~m}$ of soil.

(DOY 181) after which it began to increase, reaching a maximum of $0.270 \mathrm{mg} \mathrm{m}^{-2} \mathrm{~s}^{-1}\left(64 \mathrm{~kg} \mathrm{Cha}^{-1} \mathrm{~d}^{-1}\right)$ during anthesis (DOY 203). These maximum flux values recorded in the later half of July also coincided with maximum soil temperatures and WFPS close to $60 \%$, the optimum for soil respiration (Linn and Doran, 1984). After anthesis, average soil surface $\mathrm{CO}_{2}$ flux decreased steadily, reaching a flux of $0.074 \mathrm{mg} \mathrm{m}^{-2} \mathrm{~s}^{-1}(17 \mathrm{~kg} \mathrm{C}$ $\left.\mathrm{ha}^{-1} \mathrm{~d}^{-1}\right)$ on DOY 282 after harvest. The plots were kept well watered during the growing season and average WFPS was at least $60 \%$ until after physiological maturity (DOY 256) when irrigation had ceased. Plant population did not significantly affect soil surface $\mathrm{CO}_{2}$ flux on any of the sampling days $(p=0.09-1.0)$, even when analysis of variance was performed separately on within row and between row samples. On July 7, soil temperature was significantly lower in the $\mathrm{P} 3$ plant population than in either the $\mathrm{P} 2$ or $\mathrm{P} 1$ plant populations ( $p=0.04$ and 0.009 , respectively). On that day, LAI was considerably higher in the $\mathrm{P} 3$ plant population $(5.2 \pm 0.4)$ than in the P2 $(3.6 \pm 0.2)$ and P1 (2.7 \pm $0.9)$ plant populations. It is therefore likely that greater canopy shading caused this lower soil temperature in the $\mathrm{P} 3$ population.

The comparison of soil surface $\mathrm{CO}_{2}$ flux in the two fertility treatments of the $\mathrm{P} 2$ plant population of continuous maize is shown over a 27 -mo period in Fig. 2. Soil surface $\mathrm{CO}_{2}$ flux was significantly higher in the M2 treatment than in the M1 treatment on 24 June 1999 $(p=0.03)$ and 23 Oct. $1999(p=0.0013), 1$ wk after residue incorporation. These were the only sampling days in the entire study that any significant difference in soil surface $\mathrm{CO}_{2}$ flux was detected between the M1 and M2 fertility treatments. Flux in the control areas was significantly higher than flux in both the M1 and M2 treatments on September 9 when plants had already reached physiological maturity ( $p=0.0009$ for M2 and $p=0.0115$ for M1). Control flux was significantly higher than M2 flux on July $26(p=0.047)$ near dough stage and on August $8(p=0.009)$ near dent stage.

Soil temperature on 22 June $1999(p=0.0420)$ and 15 July $1999(p=0.0068)$ was significantly higher in the M1 treatment $\left(24.4\right.$ and $24.9^{\circ} \mathrm{C}$, respectively) than in the $\mathrm{M} 2$ treatment $\left(24.0\right.$ and $25.6^{\circ} \mathrm{C}$, respectively). Soil temperature was significantly lower in the M2 plots than in the control areas on 29 June 2000 (19.5 vs. $20.4^{\circ} \mathrm{C}$, $p=0.0222), 21$ July 2000 (20.0 vs. $20.8^{\circ} \mathrm{C}$, respectively, $p=0.0105)$, and on 8 Aug. $2000\left(24.7\right.$ vs. $25.8^{\circ} \mathrm{C}$ respectively, $p=0.0176)$. Soil temperature in the M2 plots was significantly lower than that in both the control areas and the M1 plots on 17 June 2000 (17.7, 18.2, and $18.2^{\circ} \mathrm{C}$ respectively, $p=0.0054$ and $p=0.0177$, respectively) and on 18 Aug. $2000\left(20.7,21.8\right.$, and $21.4^{\circ} \mathrm{C}$ respectively, $p<0.0001$ and $p=0.0100$, respectively). Leaf area index for the M1 and M2 treatments averaged 4.3 and 4.4, respectively, during this time period. Although LAI was not measured in the unfertilized areas, the canopy was visibly sparse, and greater penetration of sunlight may explain the slightly higher soil temperatures observed. No significant difference in WFPS was found among the fertility treatments.

Various studies have shown that the release of $\mathrm{CO}_{2}$ from decomposing soil organic matter is largely a function of soil water content and temperature (Howard and Howard, 1993). As can be seen in the data for the 2000 growing season (Fig. 2), increases and decreases in these controlling factors tended to mirror increases and decreases in soil $\mathrm{CO}_{2}$ flux. However, both soil temperature and WFPS reached maximum values earlier in the season than does soil $\mathrm{CO}_{2}$ flux, and they remained at these high values for some time after soil surface $\mathrm{CO}_{2}$ flux had dropped back down to preplant levels. Soil $\mathrm{CO}_{2}$ flux increased throughout May and June as the plant increased in biomass, reaching a maximum around anthesis. Martens (1990) reported a decrease in C translocation to the soil and declining rate of root growth as maize plants reached anthesis. While soil temperature and WFPS remained high, soil $\mathrm{CO}_{2}$ flux declined steadily throughout the rest of the growing season as more carbohydrates were allocated to grain fill and less to the roots. Soil surface $\mathrm{CO}_{2}$ flux decreased even more as the plants eventually reached physiological maturity and senescence. Qian et al. (1997) showed that root-released $\mathrm{C}$ decreases as maize plants age. While day to day variations in soil surface $\mathrm{CO}_{2}$ flux seem to mirror variations in soil temperature and moisture, the seasonal shape of the soil surface $\mathrm{CO}_{2}$ flux curve reflects an increase in biomass and root $\mathrm{C}$ allocation and then a decline in root exudates and eventual plant senescence. Singh and Gupta (1977) list phenologic stage as one of the factors governing root respiration. Soil $\mathrm{CO}_{2}$ flux measurements during the growing season represent a combination of root respiration, microbial respiration in the bulk soil, 
and respiration of the rhizosphere microbial community that predominantly uses root-released $\mathrm{C}$ as an energy source. This suggests that plant phenology exerts a great influence on soil $\mathrm{CO}_{2}$ flux through control of belowground $\mathrm{C}$ allocation.

\section{Soil Surface Carbon Dioxide Flux - Effect of Plant Roots}

Between row and within row flux, temperature, and WFPS are plotted for all sampling days during the 27mo study in Fig. 3. Within row flux was on average $64 \%$ higher than between row flux. Within row flux was higher than between row flux on all but one of the 46 sampling days that rows could be distinguished and was significantly higher than between row flux on $33 \mathrm{~d}$ ( $p$ values ranged from 0.0408 to $<0.0001$ ). Over the course of the growing season, within row flux was 10 to $198 \%$ greater than between row flux, with maximum flux differences due to location of measurement generally occurring between V12 and dent stage. However, the effect of plant roots on soil surface $\mathrm{CO}_{2}$ flux was also evident in early seedling stages and after harvest during root decomposition. In 1999, soil surface $\mathrm{CO}_{2}$ flux at the V2 stage was $16 \%$ higher within row and was significantly higher by $42 \%(p=0.0013)$ at the V2 stage in 2000. Soil surface $\mathrm{CO}_{2}$ flux was significantly higher in the within row area than in the between row area by $115 \%(p=0.0006) 3 \mathrm{~d}$ after harvest in 1999 and by $89 \%$ $(p<0.0001) 11 \mathrm{~d}$ after harvest in 2000.

Differences in WFPS and soil temperature were also observed between the within row and between row locations. Water-filled pore space was higher in the between row area than in the within row area on all of the 43 sampling days on which water content was measured in the two locations, and this difference was statistically significant on 35 of the $43 \mathrm{~d}(p=0.0353$ to $<0.0001)$. Over the course of the three growing seasons, WFPS in the between row area averaged $60.3 \%$ while this value was $48.1 \%$ for the within row area. Linn and Doran (1984) found that the $\mathrm{CO}_{2}$ produced from no-till soils averaged 3.7 times greater than that produced by plowed soils, presumably due to the fact that average WFPS in the surface layer of no-till soils was $62 \%$ (closer to the optimum), while that of plowed soil averaged $44 \%$. Therefore, based on WFPS alone, one would expect much higher flux in the between row area than in the within row area. Soil temperature was on average $0.5^{\circ} \mathrm{C}$ higher in the between row area than in the within row area and was significantly higher in the between row area on $14 \mathrm{~d}(p=0.0462$ to $<0.0001)$. Therefore, greater within row flux occurred even though average between row WFPS was statistically higher with an average closer to the optimum $(60 \%)$ and soil was slightly warmer between rows. This indicates a large influence of root and rhizosphere respiration on soil $\mathrm{CO}_{2}$ flux. The effect of roots on field measurements of soil respiration has been observed by various researchers. Pangle and Seiler (2002) found that soil $\mathrm{CO}_{2}$ flux was significantly higher near the base of loblolly pine seedlings compared with away from seedlings. Kessavalou et al. (1998) reported

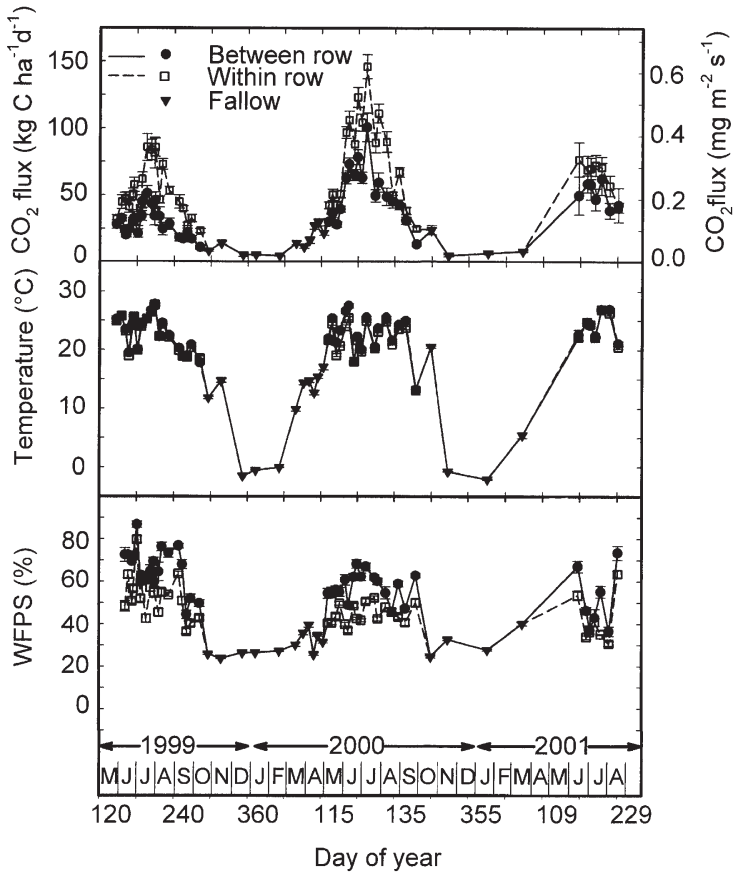

Fig. 3. Soil surface $\mathrm{CO}_{2}$ flux measured at the between row and within row locations on all sampling dates during the 27-mo study. Also shown are soil temperature at $0.1 \mathrm{~m}$ and water-filled pore space in the top $0.1 \mathrm{~m}$ of soil at the between row and within row locations. All treatments sampled for soil surface $\mathrm{CO}_{2}$ flux are included in this comparison.

that measurements of soil $\mathrm{CO}_{2}$ flux from dense areas of native grasses and rows of wheat were 1.3 to 1.5 and 1.7 to 2.9 times greater, respectively, than those from bare or between row locations. Mielnick (1996) estimated that the average seasonal contribution from root and rhizosphere respiration to soil surface $\mathrm{CO}_{2}$ flux in maize is about $54 \%$.

\section{Between Year Comparisons}

Between year differences in soil surface $\mathrm{CO}_{2}$ flux, soil temperature, and WFPS were examined by selecting a set of measurements and time period that were common to all three growing seasons. The data set was therefore limited to the M1 and M2 treatments of the P2 plant population of continuous maize since these plots were sampled in all three seasons. Measurements were limited to those made from the V8-V9 leaf stage through the last sampling day before physiological maturity to obtain three comparable data sets. This comparison among the three seasons is shown in Table 3. The 2000 season had significantly higher soil surface $\mathrm{CO}_{2}$ flux values than both the 1999 season $(p<0.0001)$ and the 2001 season $(p<0.0001)$. In addition, soil surface $\mathrm{CO}_{2}$ fluxes were significantly greater in the 2001 season than in the 1999 season $(p=0.01)$. While continuous maize plots during the first growing season of this experiment (1999) followed a previous soybean crop, the second (2000) and third (2001) growing seasons followed a previous maize crop. Residue returned to the soil after the 1998 soybean harvest was estimated to be $2.8 \mathrm{Mg} \mathrm{ha}^{-1}$, while maize residue returned to the soil after the 1999 
Table 3. Average soil surface $\mathrm{CO}_{2}$ flux and averages of WFPS and soil temperature measurements taken at time of flux measurement in the M1 and M2 treatments of the P2 (86 400-98 800 plants $\mathrm{ha}^{-1}$ ) plant population of continuous maize from V8V9 through the last sampling day before R6 during the three growing seasons.

\begin{tabular}{|c|c|c|c|}
\hline Growing season & $\begin{array}{c}\text { Soil surface } \\
\mathrm{CO}_{2} \text { flux }\end{array}$ & WFPS & Soil T \\
\hline & $\operatorname{kgCha} \mathbf{h a}^{-1} \mathbf{d}^{-1}$ & $\%$ & ${ }^{\circ} \mathbf{C}$ \\
\hline 1999 DOY 175-254 & 46.9 a $(28.1) \dagger+$ & 58.2 a (12.1) & 23.8 a $(2.8)$ \\
\hline 2000 DOY 155-231 & $79.9 \mathrm{~b}(36.5)$ & 52.6 b (12.6) & 22.8 b (2.7) \\
\hline 2001 DOY 166-230 & 58.2 c (28.5) & 46.6 c (14.5) & 24.0 a $(2.4)$ \\
\hline
\end{tabular}

$\uparrow$ Values within each column followed by the same letter do not differ significantly $(p>0.05)$ by Scheffe's procedure for analysis of variance. $\uparrow$ Number in parentheses is standard deviation.

and 2000 harvests was measured at 9.6 and $11.1 \mathrm{Mg} \mathrm{ha}^{-1}$ respectively. It is therefore likely that the significantly greater soil surface $\mathrm{CO}_{2}$ flux observed during the 2000 and 2001 growing seasons was due to a higher level of residue input and substrate decomposition.

Although soil temperature was significantly higher during the 2001 growing season as compared with the 2000 growing season, soil surface $\mathrm{CO}_{2}$ flux was significantly lower (Table 3 ). Water-filled pore space was also significantly lower during the 2001 growing season $(p=$ 0.0002 ). As mentioned previously, the method of irrigation was changed in 2001 when the drip tape was buried in alternate between row areas. Although comparable amounts of residue were added to the system before the 2000 and 2001 growing seasons, the significantly lower soil surface $\mathrm{CO}_{2}$ flux during the 2001 growing season was likely a result of drier surface soil conditions due to the change in irrigation method.

\section{Estimating Annual Soil Surface Carbon Dioxide Flux}

Since soil surface $\mathrm{CO}_{2}$ flux measurements in this study were not continuous, estimates of total flux for the fertilized plots over the course of a full year were based on an empirical equation. This equation was fitted to all data collected in the M1 and M2 plots from 11 June 1999 through 9 Sept. 2000, a total of 1322 sets of flux, WFPS, and soil temperature measurements, along with LAI estimates for each sampling day. Reports in the literature indicate that 8 to $52 \%$ of all the carbohydrates produced per day in photosynthesis are respired by the roots during the same time period, and this percentage varies widely with age of plants, growth conditions, and species (Lambers et al., 1996). It was felt that LAI, through its relationship to photosynthetic capacity and subsequent below ground $\mathrm{C}$ translocation, could serve as a parameter that would reflect the contribution of root respiration to total soil surface $\mathrm{CO}_{2}$ flux from emergence to physiological maturity. While root biomass and exudates are difficult and time-consuming to measure, LAI is a relatively simple measurement that is commonly made in agronomic studies, making it more suitable for an empirical equation such as ours. Leaf area estimates were obtained by fitting curves through available LAI data for each combination of treatment, plant population, and rotation used in the model data. A curve-fitting program using the Marquardt-Levenberg algorithm was used to determine coefficients. Data ob-

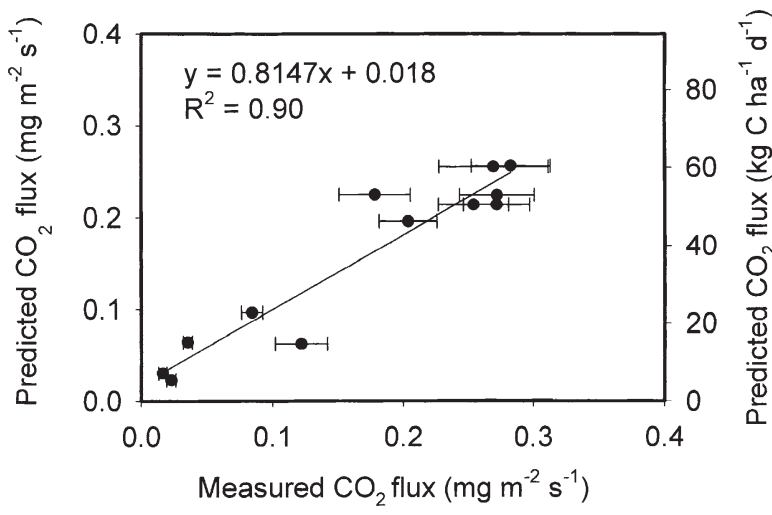

Fig. 4. Comparison of measured soil surface $\mathrm{CO}_{2}$ flux with predicted values. The empirical equation was fit to data collected from fertilized continuous maize plots from 11 June 1999 through 9 Sept. 2000. Predicted daily average values are compared with daily average flux measurements made from 26 Sept. 2000 through 18 Aug. 2001 on fertilized continuous maize plots.

tained after harvest in 2000 was not included in the curve fit to retain an independent data set with which to test the equation.

The equation uses a simple exponential relationship involving the sum of soil temperature and LAI. In addition, it incorporates a relationship between WFPS and relative soil respiration for repacked cores of 11 medium- to fine-textured soils derived by Doran et al. (1990). The coefficients of the quadratic expression of WFPS were fixed to those published by Doran et al. (1990), while the coefficients of the exponential expression of soil temperature and LAI were estimated by the Marquardt-Levenberg algorithm. This equation is as follows:

$$
\begin{aligned}
\text { flux }= & 0.053 \exp \left[0.059\left(\mathrm{~T}_{10}+\mathrm{LAI}\right)\right] \\
& \left(5.63 \mathrm{WFPS}-4.64 \mathrm{WFPS}^{2}-0.745\right)
\end{aligned}
$$

in which WFPS is water-filled pore space expressed as a fraction, $\mathrm{T}_{10}$ is soil temperature at the 0.1-m depth, and the other variables are as previously defined. The predicted residual sum of squares for this equation is $20.4, \mathrm{~F}=110.6$, and $p<0.0001$.

The equation was used to estimate daily average soil surface $\mathrm{CO}_{2}$ flux for the five sampling days from $26 \mathrm{Sept}$. 2000 through 17 Mar. 2001 on which measurements were made in the post-harvest fallow M1 and M2 plots and for the seven sampling days during the 2001 growing season (15 June 2001 through 18 Aug. 2001) on which measurements were made in the M1 and M2 treatments in continuous maize. The input data used to test Eq. [1] consisted of 200 sets of measured WFPS, measured soil temperature, and LAI values estimated from fitted curves specific to each fertility treatment. It should be stressed that this was an independent data set not used to parameterize the equations. These estimates are compared with measured daily average soil surface $\mathrm{CO}_{2}$ flux in Fig. 4. A line fitted through the data points had a slope of 0.815 , an intercept on the $y$ axis of 0.018 , and an $R^{2}$ of 0.90 , showing that it performed well at predicting these soil surface $\mathrm{CO}_{2}$ flux values, considering that daily measured and predicted flux during the 2001 growing season was based on only 16 sets of measurements. 
While the equation adequately predicted soil surface $\mathrm{CO}_{2}$ flux during the 1999 and 2001 growing seasons as well as during the winter months, it underestimated flux during the 2000 growing season. While it is likely that the greater amount of residue from the 1999 growing season caused an increase in soil respiration during the 2000 season, attempts to incorporate residue into the prediction equation caused overestimates to occur in 2001, indicating that residue amount alone does not completely explain the high fluxes in 2000. Therefore, the prediction equation was fitted specifically to the 2000 data to estimate total soil surface $\mathrm{CO}_{2}$ flux over an entire year for the fertilized continuous maize plots. This particular year was chosen because soil moisture data were available for all sampling days throughout the entire year. The equation fitted to the 2000 data is as follows:

$$
\begin{aligned}
\text { flux }= & 0.044 \exp \left[0.076\left(\mathrm{~T}_{10}+\mathrm{LAI}\right)\right] \\
& \left(5.63 \mathrm{WFPS}-4.64 \mathrm{WFPS}^{2}-0.745\right)
\end{aligned}
$$

Equation [2] was used to calculate hourly or half hourly flux for the M1 and M2 treatments of P2. Soil temperature input for Eq. [2] consisted of half hourly soil temperature readings at $0.1 \mathrm{~m}$ from an automated weather station (AWS) located in the center of the study center (DOY 8-256) or hourly 0.1-m soil temperature readings from an AWS located in a grassy field within $250 \mathrm{~m}$ of the study area (DOY 1-7 and 257-366). Leaf area index values for Eq. [2] were estimated from fitted curves, and WFPS values were estimated by interpolating between measured daily values. Hourly and half hourly soil $\mathrm{CO}_{2}$ flux estimates were averaged over each 24 -h period. Integration under curves of predicted flux plotted against day of year yielded an emission estimate of $11500 \mathrm{~kg} \mathrm{C} \mathrm{ha}^{-1} \mathrm{yr}^{-1}$ for the M1 treatment and 11600 $\mathrm{kg} \mathrm{C} \mathrm{ha}{ }^{-1} \mathrm{yr}^{-1}$ for the M2 treatment. Therefore, based on both actual flux measurements and estimated values, it seems that the intensive fertility treatment results in little difference in soil surface $\mathrm{CO}_{2}$ flux compared with the standard recommended treatment (M1). However, intensive levels of $\mathrm{N}$ application may have an indirect effect on soil $\mathrm{CO}_{2}$ flux, as declining $\mathrm{pH}$ levels necessitate increased lime applications, which in turn, potentially increase soil surface $\mathrm{CO}_{2}$ flux as neutralization of the soil solution proceeds.

\section{Nitrous Oxide, Methane, Electrical Conductivity, $\mathrm{NO}_{3}^{-}-\mathrm{N}$, and $\mathbf{p H}$}

Measurements made of $\mathrm{N}_{2} \mathrm{O}$ flux, $\mathrm{CH}_{4}$ flux, and EC during the 2000 and 2001 growing seasons and $\mathrm{NO}_{3}^{-}-\mathrm{N}$ and $\mathrm{pH}$ during the 2001 growing season are shown in Table 4. While no significant difference in $\mathrm{N}_{2} \mathrm{O}$ flux was seen between the fertilized treatments on 23 May 2000 after M1 and M2 plots had received identical amounts of preplant $\mathrm{N}$ (see Table 1.), a significant difference was seen on 12 July, $49 \mathrm{~d}$ after an additional $100 \mathrm{~kg} \mathrm{~N} \mathrm{ha}^{-1}$ had been applied to the M1 treatment and $34 \mathrm{~d}$ after an additional $263 \mathrm{~kg} \mathrm{~N} \mathrm{ha}^{-1}$ had been applied to the M2 treatment. The greater amount of $\mathrm{N}$ applied to the intensive treatment resulted in a significantly higher $\mathrm{N}_{2} \mathrm{O}$ flux in comparison with both the M1 treatment
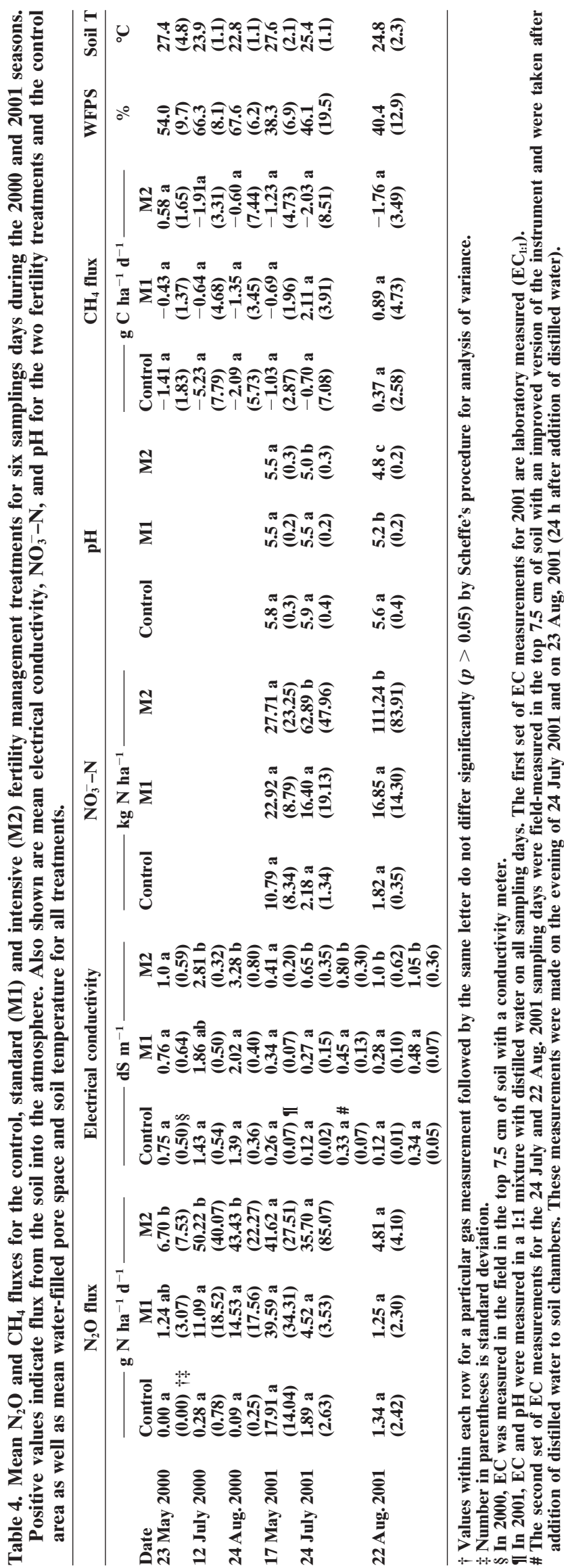
and the unfertilized control, and this effect was still evident when measurements of $\mathrm{N}_{2} \mathrm{O}$ flux were made 11 wk after the final fertilizer application (August 24). Field measured electrical conductivity was significantly higher in the M2 treatment later in the season. A good correlation $\left(R^{2}=0.89\right)$ was seen between field-measured EC for the two fertility treatments and $\mathrm{N}_{2} \mathrm{O}$ flux in 2000 (Fig. 5). In this figure, electrical conductivity values were adjusted to account for naturally occurring anions not related to fertilizer inputs by subtracting EC values measured on the same day in the control areas (Smith and Doran, 1996). This strong relationship was not seen in 2001 when distilled water was added to the chambers before EC measurement. No significant differences in $\mathrm{CH}_{4}$ flux were observed during the 2000 season.

There were no significant differences in $\mathrm{N}_{2} \mathrm{O}$ flux among the control and the two fertility treatments during the 2001 growing season, even after the full fertility treatments were applied. In addition, M2 fluxes were generally lower later in the season. Even the apparently high M2 flux on 24 July $\left(35.7 \mathrm{~g} \mathrm{~N} \mathrm{ha}^{-1} \mathrm{~d}^{-1}\right)$ is due to samples taken from a single chamber placed where there had been standing water for $4 \mathrm{~d}$ due to leakage during irrigation the previous week. At the time fluxes were measured, surface water had drained from this area, but WFPS near this chamber was still relatively high at $86 \%$. Nitrous oxide flux measured at this particular chamber was $246 \mathrm{~g} \mathrm{~N} \mathrm{ha}^{-1} \mathrm{~d}^{-1}$. Without including the flux calculation from samples taken from this particular chamber, average $\mathrm{N}_{2} \mathrm{O}$ flux for the M2 treatment on 24 July 2001 would be only $5.67 \mathrm{~g} \mathrm{~N} \mathrm{ha}^{-1} \mathrm{~d}^{-1}$ with a standard deviation of 5.45. As in 2000, there were no significant differences in $\mathrm{CH}_{4}$ flux among the treatments in 2001.

There are several possible reasons for the difference in the pattern of $\mathrm{N}_{2} \mathrm{O}$ flux seen in the two growing seasons. While two splits of $\mathrm{N}$ were applied to the growing crop in 2000, this application was spread out over three splits in 2001. This change in timing of $\mathrm{N}$ application in the M2 treatment may have allowed for more efficient uptake of $\mathrm{NO}_{3}^{-}$by the plants, therefore making it less available for denitrification. Also, lower $\mathrm{NO}_{3}^{-}$

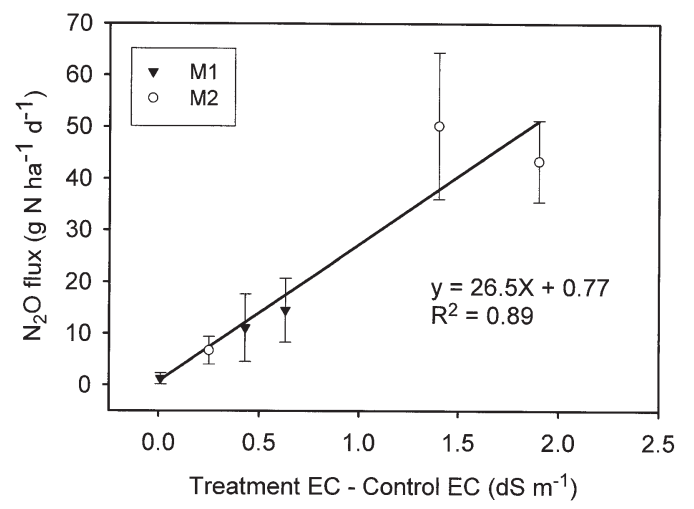

Fig. 5. Mean nitrous oxide flux measured on 23 May, 12 July, and 24 Aug 2000 for the two fertility treatments $(\mathrm{M1}=$ recommended best management; $M 2$ = intensive) plotted against the difference between treatment means for field-measured electrical conductivity (EC) and mean EC measured in unfertilized control areas on the same sampling days. levels throughout the growing season would allow for a lower $\mathrm{N}_{2} \mathrm{O} / \mathrm{N}_{2}$ ratio in denitrification products. Increased levels of $\mathrm{NO}_{3}^{-}$seem to inhibit the reduction of $\mathrm{N}_{2} \mathrm{O}$ to $\mathrm{N}_{2}$ during denitrification, thus increasing the $\mathrm{N}_{2} \mathrm{O} / \mathrm{N}_{2}$ ratio of the products (Blackmer and Bremner, 1978; Smith and Doran, 1996). Since $\mathrm{NO}_{3}^{-}-\mathrm{N}$ levels were not measured during the 2000 growing season, it is not possible to verify whether or not they were lower in the M2 treatment in 2001. However, as seen in Table 4, $\mathrm{NO}_{3}^{-}-\mathrm{N}$ levels measured in the top $7.5 \mathrm{~cm}$ in 2001 proved to be significantly higher in the M2 plots than in either the control areas or the M1 plots on 24 July and 22 August ( $p$ values ranged from 0.0009 to 0.0184 ).

Based on the considerably higher $\mathrm{NO}_{3}^{-}$levels in the $\mathrm{M} 2$ treatment, one would expect that $\mathrm{N}_{2} \mathrm{O}$ flux would again be significantly higher in the M2 treatment than in the M1 treatment and the control area. However, the soil surface layer was generally drier in 2001 due to the change in irrigation technique. It is possible that the potential for high rates of denitrification existed in the M2 treatment in 2001, but that this potential was not met due to a generally lower WFPS. As mentioned previously, standing water in the area of one of the M2 chambers seemed to trigger an extremely high $\mathrm{N}_{2} \mathrm{O}$ flux $(246 \mathrm{~g}$ $\mathrm{N}$ ha ${ }^{-1} \mathrm{~d}^{-1}$ ), which contributed to the high standard deviation on 24 July.

A third possible explanation for the lower $\mathrm{N}_{2} \mathrm{O}$ fluxes later in the 2001 season in the M2 treatment is the progressive lowering of soil solution $\mathrm{pH}$ due to greater nitrification of $\mathrm{NH}_{4}^{+}$applied at a higher rate. If the resulting $\mathrm{NO}_{3}^{-}$had exceeded plant requirements, excess hydronium ions produced during nitrification would not have been sufficiently neutralized during $\mathrm{NO}_{3}^{-}$uptake. Patriquin et al. (1993) describe how this decoupling of soil-plant $\mathrm{N}$ cycling also decouples the cycling of protons and can result in acidification of soil. By the time the third set of measurements was taken on August 22 and the full $\mathrm{N}$ rates had been applied, nitrification of $\mathrm{NH}_{4}^{+}$had caused the $\mathrm{pH}$ in both treatments to drop to levels significantly lower than the control area. In the M2 treatment, $\mathrm{pH}$ dropped to 4.8, a level significantly lower than that of the M1 treatment. It is possible that this low $\mathrm{pH}$ inhibited the microorganisms involved in the $\mathrm{N}$ transformations that produce $\mathrm{N}_{2} \mathrm{O}$. While both nitrification and denitrification have an optimum $\mathrm{pH}$ range of 6.5 to 8 (Smith and Doran, 1996), nitrification is especially sensitive to low $\mathrm{pH}$, and its rate becomes negligible below pH 5.0 (Bouwman, 1990). Since WFPS was generally below $80 \%$, a level above which denitrification rates increase sharply (Linn and Doran, 1984), it is likely that nitrification was the major source of $\mathrm{N}_{2} \mathrm{O}$ in this system and its production could have been decreased by lowering $\mathrm{pH}$ levels. Electrical conductivity was significantly higher than both the M1 treatment and the control in 2001. Laboratory measured $\mathrm{EC}_{1: 1}$ was highly correlated with $\mathrm{NO}_{3}^{-}-\mathrm{N}$ concentration for individual soil samples $\left(R^{2}=0.91\right)$, suggesting that the relatively high EC values found in many of the M2 samples were a result of the greater amounts of $\mathrm{N}$ fertilizer applied in that treatment. 


\section{CONCLUSIONS}

The results of this study suggest that $\mathrm{C}$ sequestration measures that attempt to increase the amount of crop residue returned to the soil through increased plant population or increased $\mathrm{N}$ inputs do not have an immediate effect on soil surface $\mathrm{CO}_{2}$ flux. While fertility management seemed to have no effect on $\mathrm{CH}_{4}$ flux in this study, higher levels of $\mathrm{N}$ application significantly increased $\mathrm{N}_{2} \mathrm{O}$ flux during a growing season when the high $\mathrm{N}$ treatment was applied in two splits and plots were watered through surface irrigation tape. The effect of high $\mathrm{N}$ inputs on $\mathrm{N}_{2} \mathrm{O}$ flux was not as apparent during a season when plots were watered through buried irrigation tape and the high $\mathrm{N}$ treatment was applied in three splits, covering a longer phase of crop development. These results suggest that the potential for $\mathrm{N}_{2} \mathrm{O}$ emissions from agricultural soils may be lowered by changes in fertility and irrigation management.

\section{ACKNOWLEDGMENTS}

We thank Spencer Arnold of the USDA-ARS Soil and Water Conservation Unit for gas chromatography analysis and John Lindquist of the Department of Agronomy and Horticulture at UNL for the use of LAI data. The Ecological Intensification of Irrigated Maize-based Cropping Systems Experiment at UNL is supported by the Fluid Fertilizer Foundation (FFF), the Foundation for Agronomic Research (Potash \& Phosphate Institute and IMC Global, Inc.) and the Nebraska Corn Board.

\section{REFERENCES}

Arnold, S.L., T.B. Parkin, J.W. Doran, B. Eghball, and A.R. Mosier. 2001. Automated gas sampling system for laboratory analysis of $\mathrm{CH}_{4}$ and $\mathrm{N}_{2} \mathrm{O}$. Commun. Soil Sci. Plant Anal. 32:2795-2807.

Beauchamp, E.G. 1997. Nitrous oxide emission from agricultural soils. Can. J. Soil Sci. 77:113-123.

Blackmer, A.M., and J.M. Bremner. 1978. Inhibitory effect of nitrate on reduction of $\mathrm{N}_{2} \mathrm{O}$ to $\mathrm{N}_{2}$ by soil microorganisms. Soil Biol. Biochem. 10:187-191.

Bouwman, A.F. 1990. Exchange of greenhouse gases between terrestrial ecosystems and the atmosphere. p. 61-127. In A.F. Bouwman (ed.) Soils and the greenhouse effect. John Wiley \& Sons, Chichester, UK.

Bronson, K.F., and A.R. Mosier. 1993. Nitrous oxide emissions and methane consumption in wheat and corn-cropped systems in northeastern Colorado. p. 133-144 In Agricultural ecosystem effects on trace gases and global climate change. ASA Spec. Publ. 55. ASA, CSSA, and SSSA, Madison, WI.

Doran, J.W., L.N. Mielke, and J.F. Power. 1990. Microbial activity as regulated by soil water-filled pore space. p. 94-99. In Trans. Int. Congr. Soil Sci., 14th, Kyoto, Japan. 12-18 Aug. 1990.

Firestone, M.K., and E.A. Davidson. 1989. Microbiological basis of $\mathrm{NO}$ and $\mathrm{N}_{2} \mathrm{O}$ production and consumption in soil. p. 7-21. In M.O. Andreae and D.S. Schimel (ed.) Report of the Dahlem workshop on exchange of trace gases between terrestrial ecosystems and the atmosphere. John Wiley \& Sons, Chichester, UK.

Gelderman, R.H., and D. Beegle. 1998. Nitrate-nitrogen. p. 17-20. In Recommended chemical soil test. procedures for the North Central Region. North Central Regional Publication No. 221. Missouri Agric. Exp. Stn., Columbia, MO.

Howard, D.M., and P.J.A. Howard. 1993. Relationships between $\mathrm{CO}_{2}$ evolution, moisture content and temperature for a range of soil types. Soil Biol. Biochem. 25:1537-1546.

Hutchinson, G.L., and A.R. Mosier. 1981. Improved soil cover method for field measurement of nitrous oxide fluxes. Soil Sci. Soc. Am. J. 45:311-316.

IPCC. 2001. Climate change 2001: The scientific basis: Contribution of Working Group 1 to the third assessment report of the Intergovernmental Panel on Climate Change. Cambridge University Press, Cambridge, UK.

Kessavalou, A., A.R. Mosier, J.W. Doran, R.A. Drijber, D.J. Lyon, and O. Heinemeyer. 1998. Fluxes of carbon dioxide, nitrous oxide, and methane in grass sod and winter wheat-fallow tillage management. J. Environ. Qual. 27:1094-1104.

Lal, R., J.M. Kimble, and R.F. Follett. 1998. Need for research and need for action. p. 447-454. In R. Lal et al. (ed.) Management of carbon sequestration in soil. Adv. Soil Sci. CRC Press, Boca Raton, FL.

Lambers, H., I. Scheurwater, and O.K. Atkin. 1996. Respiratory patterns in roots in relation to their functioning. p. 323-362. In Y. Waisel et al. (ed.) Plant roots: The hidden half. Marcel Dekker, Inc., New York.

Linn, D.M., and J.W. Doran. 1984. Effect of water-filled pore space on carbon dioxide and nitrous oxide production in tilled and nontilled soils. Soil Sci. Soc. Am. J. 48:1267-1272.

Martens, R. 1990. Contribution of rhizodeposits to the maintenance and growth of soil microbial biomass. Soil Biol. Biochem. 22:141147.

Mielnick, P.C. 1996. Soil carbon dioxide flux in agricultural ecosystems. Ph.D. diss. Univ. of Nebraska, Lincoln.

Norman, J.M., R. Garcia, and S.B. Verma. 1992. Soil surface $\mathrm{CO}_{2}$ fluxes and the carbon budget of a grassland. J. Geophys. Res. 97: $18,845-18,853$.

Pangle, R.E., and J. Seiler. 2002. Influence of seedling roots, environmental factors and soil characteristics on soil $\mathrm{CO}_{2}$ efflux rates in a 2-year-old loblolly pine (Pinus taeda L.) plantation in the Virginia Piedmont. Environ. Pollut. 116 (Suppl. 1):s85-s96.

Patriquin, D.G., H. Blaikie, M.J. Patriquin, and C. Yang. 1993. Onfarm measurements of $\mathrm{pH}$, electrical conductivity and nitrate in soil extracts for monitoring coupling and decoupling of nutrient cycles. Biol. Agric. Hortic. 9:231-272.

Powlson, D.S., K.W.T. Goulding, T.W. Willison, C.P. Webster, and B.W. Hütsch. 1997. The effect of agriculture on methane oxidation in soil. Nutr. Cycling Agroecosyst. 49:59-70.

Qian, J.H., J.W. Doran, and D.T. Walters. 1997. Maize plant contributions to root zone available carbon and microbial transformations of nitrogen. Soil Biol. Biochem. 29:1451-1462.

Raich, J.W., and C.S. Potter. 1995. Global patterns of carbon dioxide emissions from soil. Global Biogeochem. Cycle 9:23-36.

Robertson, G.P. 1993. Fluxes of nitrous oxide and other nitrogen trace gases from intensively managed landscapes: A global perspective. p. 95-108. In Agricultural ecosystem effects on trace gases and global climate change. ASA Special Pub. No. 55. ASA, CSSA, and SSSA, Madison WI.

Rochette, P., and E.G. Gregorich. 1998. Dynamics of soil microbial biomass $\mathrm{C}$, soluble organic $\mathrm{C}$ and $\mathrm{CO}_{2}$ evolution after three years of manure application. Can. J. Soil Sci. 78:283-290.

Singh, J.S., and S.R. Gupta. 1977. Plant decomposition and soil respiration in terrestrial ecosystems. Bot. Rev. 43:449-528.

Smith, J.L., and J.W. Doran. 1996. Measurement and use of $\mathrm{pH}$ and electrical conductivity for soil quality analysis. p. 169-185. In J.W. Doran and A.J. Jones (ed.) Methods for assessing soil quality. SSSA Spec. Publ. No. 49. SSSA, Madison, WI.

Sylvia, D.M., J.J. Fuhrmann, P.G. Hartel, and D.A. Zuberer. 1998. Principles and applications of soil microbiology. Prentice Hall, Upper Saddle River, NJ.

Varvel, G.E. 1994. Rotation and nitrogen fertilization effects on changes in soil carbon and nitrogen. Agron. J. 86:319-325.

Wagai, R., K.R. Brye, S.T. Gower, J.M. Norman, and L.G. Bundy. 1998. Land use and environmental factors influencing soil surface $\mathrm{CO}_{2}$ flux and microbial biomass in natural and managed ecosystems in southern Wisconsin. Soil Biol. Biochem. 30:1501-1509. 